\title{
Assessing Community Resilience to Flood Disasters in Rural District of Da Nang City, Vietnam
}

\author{
ベトナム・ダナン市農村部における洪水災害に対するコミュニティレジリエンスの評価 \\ Do Thi Viet HuOnG*, Kazunobu TsuTsui**, Ryota NAGASAWA*** \\ ドティヴィエットフオン*，筒井一伸**，長澤良太*** \\ *The United Graduate School of Agricultural Sciences, Tottori University, \\ **Faculty of Regional Sciences, Tottori University, ${ }^{* * *}$ Faculty of Agriculture, Tottori University \\ *鳥取大学大学院連合農学研究科, ${ }^{* *}$ 鳥取大学地域学部, ${ }^{* * *}$ 鳥取大学農学部
}

\section{Introduction}

Resilience and vulnerability have been increasingly considered as vital components of disaster risk reduction since the adoption of the Hyogo Framework for Action 2005-2015 at the World Conference on Disaster Reduction in Kobe, Japan (Cutter et al., 2008; ISDR, 2005). The vulnerability and what disaster analysts call "risk burdens" of communities and countries are progressing on a global scale, leading national and local governments, donors and many others evaluate the necessity of minimizing the associated natural disaster impacts by implementing disaster management principles and practices (Ainunddin, 2012; ISDR, 2004). Recent models have shifted away from post disaster relief or "loss reduction", "reducing vulnerability" models to more comprehensive models of "building community resilience", which shift people's attitudes and behaviors towards coping with natural disasters, analyzing vulnerability, and building community resilience (Cutter et al., 2008; Mayunga, 2007; ISDR, 2004).

Community resilience refers to community capacities to establish emergency plans and be ready for change whilst retaining the ability to be flexible and responsive to the uniqueness of the presenting situation (Wickes et al., 2010). The studies on community resilience to disasters have been emerged since communities and people are becoming increasingly more vulnerable to natural hazards (floods, hurricanes, typhoons, tsunami...) due to worldwide climate change and environment issues (Wilson, 2012, Shaw and Sharma, 2011, ACCCRN, 2009, Mayunaga, 2007; U.S. Indian Ocean Tsunami Warning System Program, 2007). Wilson (2012) and Mayunaga (2007) have investigated the community disaster resilience by utilizing the capital - based approach such as social, economic, human, physical, environment and natural capital of community whereas ACCCRN (2009) approached community resilience assessment to flood and storm disasters focusing on urban cities by examining four elements of urban resilience including redundancy, flexibility, capacity to reorganize, and capacity to learn. Shaw and Sharma, 2011 also paid more attention to mapping climate and disaster resilience in urban areas based on Climate Disaster Resilience Index (CDRI) encompassing physical, social, economic, institutional, and natural dimensions. The Tohoku Earthquake (Great East Japan Earthquake) which occurred on 11th March 2011 was the most powerful known earthquake ever hit to Japan causing approximately 19,500 dead and missing people, 115,000 building totally destroyed and 162,000 half destroyed (Japan ICOMOS National Committee). Inotaga (2012) had discussed the related community resilience issues in his study on the resilience of rural community through emigration and return who experienced the catastrophe earthquake. Three month later, Thailand suffered the worst floods in more than half a century causing prolonged, widespread flooding and affecting more than 13 million people from July to December. The Royal Thai Government had collaborated with World Bank in conducting the rapid assessment for resilient recovery and reconstruction planning. Although researches on community resilience to disaster are still in its infancy, they have contributed the foundation for reducing vulnerability and disaster risk and for achieving sustainable development in recent years.

Vietnam is located in the tropical monsoon region of South East Asia, one of the most hazard-prone areas in the Asia Pacific Region. An estimated 70 percent of the Vietnamese people are exposed to risks from natural hazards (typhoons, tropical storms, floods, landslides, and droughts) - especially in rural communities, where livelihoods are most threatened (World Bank, 2013). The Central Region of Vietnam, which is a long, narrow region with a complex sloping terrain stretching along the coastline, in particular suffers the most frequent and devastating effects of flood hazards. Da Nang city is one of the coastal cities suffering from consequences of natural disaster. On average each year the city is directly or indirectly influenced by 2-3 typhoons and 2-3 great floods spells. Previous average 10 years, there appeared one serious flood, however from 10 years back many severed floods have occurred such as flood events in 1999, 2006, 2007, 2009 and 2011 causing damage to all the urban districts as well as the rural areas. Hoa Vang is a suburban/ rural district of Da Nang city and is considered one of the major areas affected by natural disasters (typhoon, inundation, and flash flooding) causing damage to life, houses, infrastructure, and agriculture products during the last 10 years (People's Committee of Da Nang, 2009). The livelihood conditions of the local residents in this area are still substandard with an estimated of 3,783 households at the poverty level (Hoa Vang Statistical Office, 2011). In addition, the weather events are likely to become less predictable and so more intense in future due to climate change. In the author's previous published paper on flood risk in Da Nang city (Huong et al., 2013), the results reveals that most of the rural communes in Hoa Vang district are exposed to flood risk at high or moderate level. Therefore, it is necessary to conduct the research on how to mitigate flood disaster risk as well as to improve the resilience community in these rural areas as case study in this paper. 
There has been an apparent increase the awareness of the importance of prevention and mitigation of natural disasters in rural sustainable development in recent years. Vietnam Government in general and Da Nang Authority in particular have issued a number of policies related to natural disaster management. For instance, in 2007, Vietnam Government issued the National Strategy for Natural Disaster Prevention, Response and Mitigation to 2020 (Decision No.158/200/QĐ-TTg on November $2^{\text {nd }} 2008$ ), and Da Nang city authority also subsequently approved the Action Plan of Responding to Climate Change and Sea Level Rise to 2020 (Decision No.6901/QĐ-UBND on August 24th 2012) (Vietnam Ministry of Natural Resources and Environment, 2008; People's Committee Da Nang, 2012). Since then, many projects in Nation and International level have been done focusing on mitigation flood disaster risk for vulnerability community as well as on building resilience community in a changing climate and environment (Centre for International Studies and Cooperation, 2008; Razafindrabe, 2009; Challenge to change and Hue University, 2009; ACCCRN, 2009). In 2008, the Centre for International Studies and Cooperation (CECI) conducted the Hydro - Meteorological Disaster Mitigation project in Da Nang city focusing on reducing vulnerability of urban communities through enhanced preparedness and mitigation of hydro-meteorological disasters. Subsequently, Razafindrabe and colleagues in 2009 also studied the resilience of urban communities in a changing climate and environment. Their results have been clarified and characterized the resilience of the new urban and coastal districts and theirs community with a special attention to water - related issues (mainly flood) in order to enhance resilience and adaptive capacity of urban government and community to these changes. The Asian Cities Climate Change Resilience Network (ACCCRN, 2009) which is a network of ten core cities in India, Indonesia, Thailand and Vietnam, has selected Da Nang as one of the study sites in Asian for building awareness and capacity on climate vulnerability and resilience. This project has been implemented to study the hazard capacity and vulnerability assessment that facilitate community-based Disaster Risk Management and resilience planning focusing in some selected urban districts of Da Nang city. From 2007-2011, the Save the Children of Vietnam organization and Holland Kingdom Government also conducted projects of Mitigation Natural disaster risk in the core center of Da Nang city. In 2010, the Mantester International has been supported for raising capacity natural disaster prevention in 11 poor communes commonly subjected to flood in Hoa Vang district by providing equipment facilities in case of emergency and improving the early flood warning. The above reviewing projects have highlighted their primary research focus on building mitigation flood disaster risk as well as resilience community mainly in Da Nang urban districts, with a lack of ample attention to rural districts which are occasionally exposed to flood disaster at a great level.

In 2010, the Vietnam Government promulgated Decision No 800/QĐ-TTg of the National Target Program on New Rural Development for entire communities until 2020. The goal is to undertake comprehensive rural development including economic, social, environmental, and political fields that concern climate change responses as well as natural disaster prevention and mitigation (Son $e t$ al., 2011). However, most of these policies are often developed on a general scale (e.g., Nationwide, North region, Central region, and South region) and little attention has been paid to a detailed regional scale based on specific geographic features, especially at village level. Hoa Vang district now is on progress of rural planning it therefore needs to integrate natural disaster prevention and mitigation into each village for New Rural sustainable development. In this study, our aim was to conduct a community resilience assessment in Hoa Vang rural district based on the potential vulnerability typology of flood affected villages and subsequently to measure the resilience of the community via a capital-based approach by using questionnaire survey. The findings of this study will serve a good reference and a scientific foundation for local authorities in flood disaster mitigation as well as sustainable development in rural area.

\section{Community Resilience Assessment framework to flood disaster}

Conceptually, the relationship between Risk, Vulnerability, and Hazards has been described as the following function: Risk = Hazard x Vulnerability, as given by the International Strategy Disaster Reduction committee (ISDR, 2004). In this sense, risk is defined as the probability of harmful consequences resulting from interactions between natural or human-induced hazards and vulnerable conditions within a social or community system. Vulnerability is defined as the characteristic of a person or group and their situation influencing their capacity to anticipate, copy with, resist, and recover from the impact of a natural hazards that threaten their life, well - being and livelihood (Wisner et al., 2003). Vulnerability used here does not imply the adoption of a pathogenic framework but indeed contains elements (e.g., "cope with", "resist") consistent with the concept of resilience (Paton et al., 2000). Vulnerability registered not only by exposure to hazards alone but also resides in the resilience of the system experiencing the hazard (Turner et al., 2003). Resilience is in part the opposite of vulnerability, but both resilience and vulnerability notions have common components of interest - the shocks and stresses, the response of the system, and the capacity for adaptive action (Wilson, 2012; Adger, 2006; Adger, 2000). From a social perspective, resilience/vulnerability has been imbedded in the notion of communities with "good resilience" or "bad vulnerability" and appears as a simple spectrum where the extreme end is clearly recognized as resilience/vulnerability (Wilson, 2012). The "good resilience" refers to the ability of a human system to absorb disturbance and to reorganize to become fully functional - a "positive" quality. In contrast, "bad resilience" is associated with the exposure and sensitivity of a human system that is unable to cope with risks, hazards, and slow or catastrophic change - a "negative quality" (Wilson, 2012; Cutter et al., 2008). Risk can be reduced by minimizing the degree of vulnerability within the entire community or, in other words, by enhancing the resilience of the community. Therefore, examination of the resilience in relation to vulnerability and risk is an essential conceptual framework for understanding how communities respond and adapt to natural disasters, in order to assess community resilience.

The term "Resilience" has been defined in a variety of scientific disciplines as the notion of "bouncing back" or "recoiling", and originated from the Latin word "resilio" (Klein et al., 2013; Wilson, 2012). A high degree of agreement is evident in the literature in support of the concept that resilience was first focused on notions of ecological resilience (Cutter et al., 2008; Folke et al., 2006; Holling, 1973). Since the first work of the ecologist Holling on ecosystem fields, the concept of resilience has been emerging and used 
in a variety of interdisciplinary fields associated with the interactions between people and nature, including vulnerability, hazards, and disaster reduction (Manyena, 2006; Klein et al., 2003). In this research domain, we focus on community resilience to disaster, which was defined as the ability of a group or community to respond to and recover from disaster and includes those inherent conditions that allow the system to absorb impacts and cope with an event, as well as post-events, and adaptive processes that facilitate the ability of the social systems to re-organize, change, and learn in response to a threat (Cutter et al., 2008; Adger, 2000). Community here is defined as an entity with geographic boundaries (e.g., a village) where people or a group of people have similar characteristics, relate to each other as a community and share a common physical, environmental, economic, relational, political or social ways (Kumar, 2005). The concept of community resilience is increasingly being embraced as a framework for enhancing disaster readiness and response capability (Sherrieb et al., 2012). However, assessing community resilience is a complicated process due to the dynamic interaction of populations, communities, and societies as well as the environment (Mayunga, 2007). A number of models and frameworks have been developed in order to assess

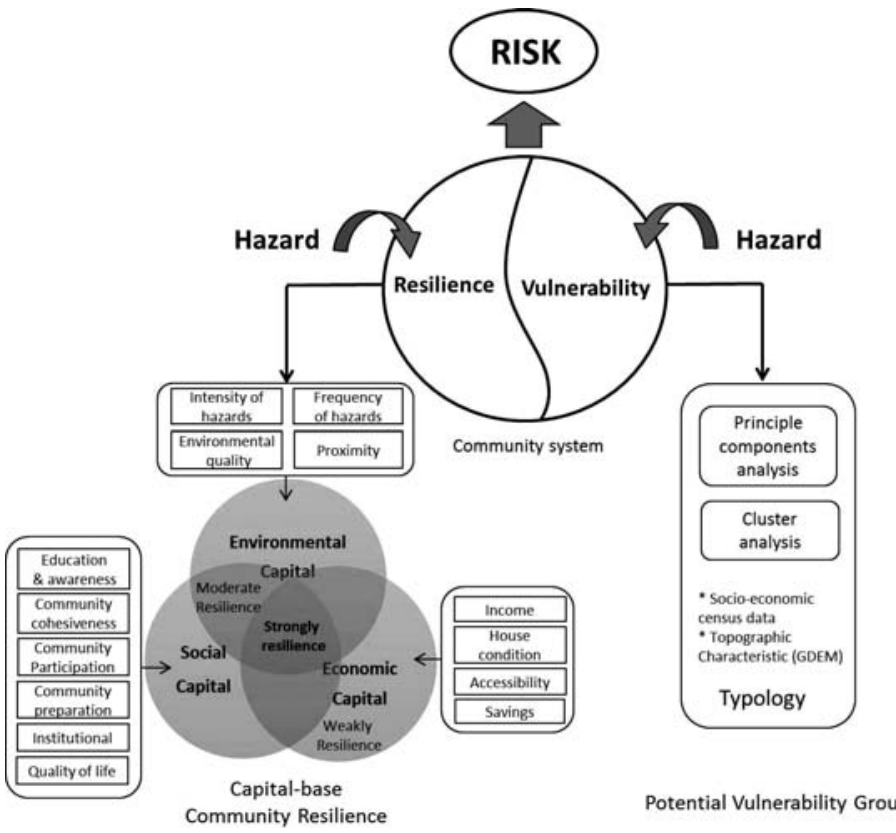

Fig. 1 Conceptual framework of Community Resilience Assessment (Modified from Wilson G.A., 2012)

community resilience (Wilson, 2012; Cutter et al., 2008; Norris, 2008; Mayunga, 2007). Cutter et al. (2008) employed six dimensions for assessing community resilience including ecological, social, economic, institutional, infrastructure, and community competence whereas Norris and colleagues identified four primary sets of capacities for community resilience: Economic Development, Social Capital, Information, and Communication Competence (with 19 indicators). Mayunaga (2007) utilized five major forms of capital which can contribute to reducing vulnerability and increasing community disaster resilience, i.e., social capital, economic capital, human capital, physical capital, natural capital encompassing 15 indicators. In investigating the impacts of globalization processes on community resilience, Wilson (2012) proposed a framework focusing on a social resilience approach for understanding community resilience as a conceptual space as the intersection between economic, social, and environmental capital including 36 indicators. Although these frameworks conceptualize the dimensions of community resilience with relatively different expression, they seem to focus on the community capital that could reduce vulnerability and enhance community resilience.

This paper utilized the community resilience framework given by Wilson (2012) as its conceptual basis for assessment community resilience since it applies to natural disasters, particularly flood disasters. This framework enables any studies to apply its various indicators (36 indicators) as well as loose questions list (154 questions) in investigating socio, economic, and environmental capital. The advantage of this framework is that there is no prescription about how many indicators and questions are needed to assess each of the three capitals. The number of indicators and questions for addressing each capital will vary depending on research questions, types of disturbance, specific resilience issues under investigation as well as the complexity of community structure (Wilson, 2012). The conceptual framework of Community Resilience Assessment is depicted in Figure 1 through the relationship between Risk, Hazard, Vulnerability, and Resilience. Community resilience was measured based on the capital-based community resilience, which represented an interaction between the three capital pillars of resilience: economic capital, social capital, and environmental capital. Each capital has several corresponding variables that are used to measure the degree of resilience of a given community. The strongest form of community resilience can be found at the intersection between strong economic, social, and environmental capital. A community where only two of these capitals are well developed can be characterized as only moderately resilient, or indeed as moderately vulnerable, while a community that has only one (or no) well-developed capital is generally characterized as weakly resilient/highly vulnerable (Wilson, 2012). The community resilience assessment was conducted based on typology and a questionnaire survey, which will be clearly explained in the following methodology section.

\section{Methodology}

\section{Typology of the potential vulnerability of flood affected villages}

Socio-economic typology is one effective method for grouping diverse geographic objects into entity groups or certain classes with similar characteristics and certain indicators for socio-economic territory organization (Thinh and Duc, 2005). An attempt to quantitatively classify by a typology using socio-economic data was made by Tsutsui (2005) in regions of Vietnam, who utilized principle analysis and cluster analysis for this research. In the present study, this technique was used not only to establish similar social characteristics but also to group the topographic characteristic of flood affected villages in the Hoa Vang rural district, thereby providing the background for assessing community resilience to flood disaster. Social indicators such as population employees per economy sector, 
Table 1 Variables used for typology

\begin{tabular}{clcc} 
No & \multicolumn{1}{c}{ Variable } & Unit & Year \\
\hline 1 & Population & person & 2011 \\
2 & Number of hh & hh & 2011 \\
3 & Scale of hh & people/hh & 2009 \\
4 & Dependent population rate & $\%$ & 2009 \\
5 & Population in working age rate & $\%$ & 2011 \\
6 & Agriculture Forestry Aquaculture hh rate & $\%$ & 2011 \\
7 & Industry - Construction hh rate & $\%$ & 2011 \\
8 & Business - Service hh rate & $\%$ & 2011 \\
9 & Poverty hh rate & $\%$ & 2009 \\
10 & Using sanitary latrineshh rate & $\%$ & 2009 \\
11 & Have no latrines hh rate & $\%$ & 2009 \\
12 & Permanent and semi-permanent hh rate & $\%$ & 2009 \\
13 & Temporaryhh rate & $\%$ & 2009 \\
14 & Using running waterhh rate & $\%$ & 2009 \\
15 & Using well waterhh rate & $\%$ & 2009 \\
16 & Using TVhh rate & $\%$ & 2009 \\
17 & Having motorcyclehh rate & $\%$ & 2009 \\
18 & Having table telephone hh rate & $\%$ & 2009 \\
19 & Having radiohh rate & $\%$ & 2009 \\
20 & Average elevation & $\mathrm{m}$ & $\mathrm{GDEM}$ \\
Abbreviation: hh = household & &
\end{tabular}

Source: Hoa Vang Statistical Office, 2011; Da Nang Statistical Office, 2010.

and households at the poverty level, as well livelihood conditions are the significant factors that identify vulnerability (Fekete, 2009; Kienberger et al., 2009). Therefore, typology in this research is based on the analysis of 19 variables obtained from census data of the Hoa Vang District including characteristics of demography (1-4), labor and employment (5-8), and living condition (9-19); 1 variable of topographic characteristic extracting from GDEM for classifying the potential vulnerability groups of flood affected villages (Table 1). Two statistical analysis techniques used in typology include principal component analysis and cluster analysis (Ward's method).

Hoa Vang is a suburban of Da Nang city, which includes 11 communes and 118 villages. The topography here is very diverse, combining mountains, hill and plain areas, where the mountainous area dominates (79.84\%) (Figure 2). As already mentioned, Hoa Vang is a rural district and annually exposed to natural disasters, especially flood disasters including riverine flood and flash flood. According to Natural disaster report of Da Nang's Committee for Flood and Storm Control (2008), a total of 11/11 communes and

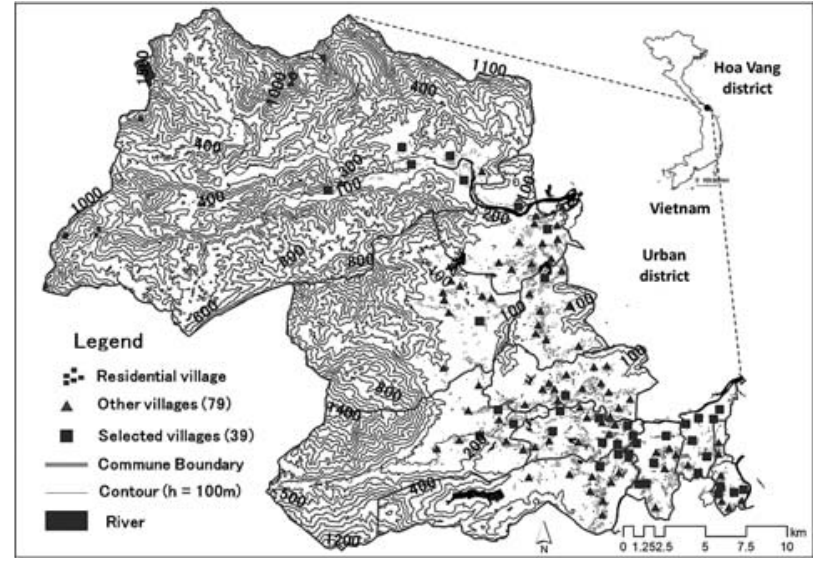

Fig. 2 Location of study area
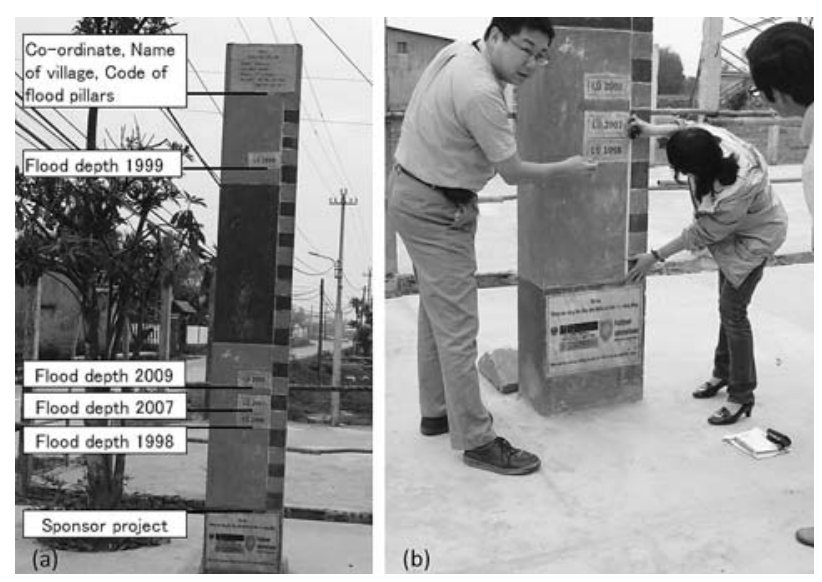

Fig. 3 Flood pillar from field survey

(a) Flood pillar structure in Thai Lai village, Hoa Nhon commune, Hoa Vang district

(b) Measure flood depth and co-ordinate of flood pillar

$87 / 118$ villages in Hoa Vang were affected in historical flood of 2007. Those villages located along rivers near the mountainous areas (Northwest of Hoa Vang) are highly exposed to flash flood, whereas the villages located in plain areas are highly exposed to riverine flood. In order to enhance the effectiveness of emergency disaster warnings contributing to reducing and preventing flood disasters, Vietnam's Ministry of Natural Resources and Environment has issued regulations of building flood pillar in local areas of the country. Flood pillar is a concrete landmark which provides some vital flood information such as the place name of flood area, code number of pillar, water warning level (I, II or III correspond to level of dangerous flood condition ${ }^{(1)}$ ) as well as flood depth level of some historical flood events (Figure 3). Flood pillar is almost located in areas of high frequency and magnitude damage of flood and have high density of residence and of easy identification. From 1999 to 2013, 39 villages of Hoa Vang district which were severely affected by flood hazards have been built with flood pillars by the local government for emergency flood disaster warnings. Based on the data from Da Nang's Committee for Flood and Storm Control and field survey results, we selected those 39 villages for cluster analysis the potential vulnerability of flood affected villages. The authors have surveyed and checked a total of 18 flood pillars within 39 flood pillars in the study areas.

\section{Questionnaire survey and community resilience measurement}

The results of typology of the potentially vulnerable villages were used to conduct questionnaire surveys in the target villages. The sample of households was limited using formula of Yamane (1967), and then the divisions in the target villages in Hoa Vang district were compared before using simple random sampling to collect the data. Questionnaires were carried out by the authors with the assistance of Hoa Vang Statistical Office's staffs experienced in survey technique, who were also involved in the piloting and final drafting of the questionnaire. The length of each household interview was around 1 hour including face to face interview with the respondent's household and capturing the location and image of household by GPS camera/handheld GPS device. In addition, several semi-structures interviews with key informants (village heads, chiefs of mass organization, public officers) were also carried out to validate and complement the information. The household interviews were conducted in June 2013. A structure questionnaire used a 
multiple - choice format which focused on the parameters of 3 dimensions defined as: (i) Economic capital, (ii) Social Capital, and (iii) Environmental Capital as mentioned in the conceptual framework of Community Resilience Assessment. Additional variables were included in the questionnaire such as geographic location, age, and gender of the respondents. Each type of capital corresponded to various variables: 11 variables were used to investigate economic capital, 26 to explore social capital, and 10 to assess environmental capital (Table 2). In this study, GIS analysis was employed to extract the variables of proximity for implementing the community resilience assessment. Firstly, images captured by handheld GPS device and GPS camerea in interviewed households were imported to map database in ArcGIS. A buffer analysis was then utilized to calculate the environment capital variables such as proximity to river, proximity to safe shelter and proximity to main road for conduct community resilience assessment in the 4 villages.

A combination of quantitative and qualitative approaches was used to analyze community resilience. The quantification of resilience for each community was based on a subjective ranking score of 1,2 , or 3 corresponding to low, medium and high resilience, respectively, referring to the community resilience and global indicators of strong and weak economic, social, and environmental capital (Wilson, 2012, Razafindrabe et al. 2009)). For example, if the question 'What is the highest flood level in your house during last 20 year?' was answered ' $2.1 \mathrm{~m}$ ', then a score of ' 1 ' (indicators of high vulnerability or low environmental resilience) was allocated. Conversely, if the question 'what is your level of your household in participating in training course on enhancing awareness of local residential' was answered 'very high' a score of 3 was given (indicator of strong social capital (Table 2). An average score was calculated for each of the three capitals and then an overall average for the three capitals was established, enabling quantitative comparison of community resilience between the target communities.

\section{Results and discussion}

\section{Potential Vulnerability groups classification}

The principle component analysis of the 20 variables resulted in extraction of five components with a cumulative percentage of the total variance of $73.74 \%$, all of which had eigenvalues of over 1 . The characteristics of each component are indicated in Table 3. The five components could be termed as follows: Level of living condition (eigenvalue: 7.6 , percentage of the total variance explained $37.8 \%)$, Scale of population $(2.5,12.3 \%)$, Level of labor force $(1.9,9.6 \%)$, Condition of occupation and household economy (1.6, 7.8\%), and Housing conditions (1.2, 6.3\%). Five groups of villages potentially vulnerable to flood disaster were delivered from a cluster analysis based on these components (Figure 4). The characteristics of 5 components allowed classification of 39 flood affected villages into five group types: (I) Very low potential vulnerability, (II) Low potential vulnerability, (III) Medium potential vulnerability, (IV) High potential vulnerability, and (V) Very high potential vulnerability (Figure 5). The results of typology and the
Table 2 Variables used in community resilience assessment

\begin{tabular}{|c|c|c|c|}
\hline pital & & Variables & Description \\
\hline \multirow{11}{*}{ 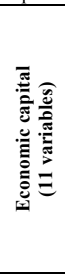 } & Income & Personal income & $<1$ millionVND $=1 ; 1-2$ millionVND $=2 ;>2$ millionVND $=3$ \\
\hline & & Diverse income & 1 source $=1 ; 2$ source $=2,>2$ source $=3$ \\
\hline & House & Storey & 1 storey $=1 ; 1$ storey + mezzanine $=2 ;>1$ storeys $=3$ \\
\hline & condition & House construction & Old $=1 ;$ Recent $=2 ;$ New $=3$ \\
\hline & & House level & $<0.5 \mathrm{~m}=1 ; 0.5-1 \mathrm{~m}=2 ;>1 \mathrm{~m}=3$ \\
\hline & Accessibility & Transport interruption & High $=1 ;$ Medium $=2 ;$ Low $=3$ \\
\hline & & Clean water access & Low $=1 ;$ Medium $=2 ; \mathrm{High}=3$ \\
\hline & & Health service access & Low $=1 ;$ Medium $=2 ;$ High $=3$ \\
\hline & & Education access & Low $=1 ;$ Medium $=2 ; \mathrm{High}=3$ \\
\hline & & Internet access & Low $=1 ;$ Medium $=2 ;$ High $=3$ \\
\hline & Savings & Savings & Don't have $=1 ;$ Maybe have $=2 ;$ Certainty have $=3$ \\
\hline \multirow{27}{*}{ 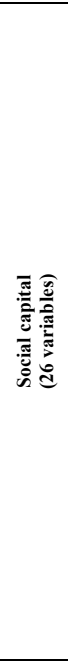 } & Education & Education & Illiterate $=1$, Under High school $=2$, Higher $=3$ \\
\hline & & Awareness & No important $=1 ;$ Normal $=2$, Important $=3$ \\
\hline & Awareness & Local knowledge & No important $=1 ;$ Normal $=2$, Important $=3$ \\
\hline & Community & Get help & Don't have $=1 ;$ Maybe have $=2 ;$ Certainty have $=3$ \\
\hline & cohesiveness & Strong cohesiveness & Low $=1 ;$ Medium $=2 ; \mathrm{High}=3$ \\
\hline & & Willing to help & Low $=1 ;$ Medium $=2 ;$ High $=3$ \\
\hline & & Community activities & Low $=1 ;$ Medium $=2 ;$ High $=3$ \\
\hline & & Discuss together & Low $=1 ;$ Medium $=2 ;$ High $=3$ \\
\hline & & Discuss leader & Low $=1 ;$ Medium $=2 ;$ High $=3$ \\
\hline & & Disaster mitigation effort & Low $=1 ;$ Medium $=2 ;$ High $=3$ \\
\hline & & Experience learning & Low $=1 ;$ Medium $=2 ; \mathrm{High}=3$ \\
\hline & & Community connectivity & Low $=1 ;$ Medium $=2 ; \mathrm{High}=3$ \\
\hline & & Trust and hope & Low $=1 ;$ Medium $=2 ; \mathrm{High}=3$ \\
\hline & & Committed to well-being & Low $=1 ;$ Medium $=2 ; \mathrm{High}=3$ \\
\hline & Quality of life & Satisfy life & Low $=1 ;$ Medium $=2 ;$ High $=3$ \\
\hline & Community & Decision making & Low $=1 ;$ Medium $=2 ;$ High $=3$ \\
\hline & participation & Training participation & Low $=1 ;$ Medium $=2 ;$ High $=3$ \\
\hline & & Women participation & Low $=1 ;$ Medium $=2 ; \mathrm{High}=3$ \\
\hline & Community & Community Preparation & Less $=1 ;$ Moderate $=2$, Good $=3$ \\
\hline & Preparation & Hazards coping plan & Don't have $=1 ;$ Maybe have $=2 ;$ Certainty have $=3$ \\
\hline & & Volunteer provision & Don't have $=1 ;$ Maybe have $=2 ;$ Certainty have $=3$ \\
\hline & Institutional & Accuracy information & Low $=1 ;$ Medium $=2 ; \mathrm{High}=3$ \\
\hline & & Effective early warning & Low $=1 ;$ Medium $=2 ;$ High $=3$ \\
\hline & & Evacuation plan & Low $=1 ;$ Medium $=2 ; \mathrm{High}=3$ \\
\hline & & During disaster support & Low $=1 ;$ Medium $=2 ;$ High $=3$ \\
\hline & & Post disaster support & Low $=1 ;$ Medium $=2 ;$ High $=3$ \\
\hline & & Trust to local government & Low $=1 ;$ Medium $=2 ; \mathrm{High}=3$ \\
\hline \multirow{10}{*}{ 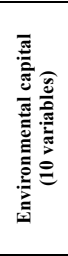 } & Intensity of & Flood depth & $>2 \mathrm{~m}=1 ; 1-2 \mathrm{~m}=2 ;<1 \mathrm{~m}=3$ \\
\hline & hazards & Flood damage & High $=1 ;$ Medium $=2 ;$ Low $=3$ \\
\hline & $\begin{array}{l}\text { Frequency of } \\
\text { hazards }\end{array}$ & Flood frequency & Frequently $=1 ;$ Medium $=2 ;$ Less frequently $=3$ \\
\hline & Environmental & Water quality & No ensure $=1 ;$ Normal $=2 ;$ Good $=3$ \\
\hline & quality & Sanitation condition & No ensure $=1 ;$ Normal $=2 ;$ Good $=3$ \\
\hline & & Solid waste & No ensure $=1 ;$ Normal $=2 ;$ Good $=3$ \\
\hline & & Drainage system & No ensure $=1 ;$ Normal $=2 ;$ Good $=3$ \\
\hline & Proximity & Proximity to river & $<100 \mathrm{~m}=1,100-200 \mathrm{~m}=2,>200 \mathrm{~m}=3$ \\
\hline & & Proximity to safe shelter & $>100 \mathrm{~m}=1,50-100 \mathrm{~m}=2,<50 \mathrm{~m}=3$ \\
\hline & & Proximity to main road & $>100 \mathrm{~m}=1,50-100 \mathrm{~m}=2,<50 \mathrm{~m}=3$ \\
\hline
\end{tabular}

Source: Modified from Wilson, 2012; Sherrieb et al., 2012; Pfefferbaum et al., 2011; Joerin and Shaw, 2011. 
flood depth pillar values from the field survey were used to select the village with the highest historical flood depth in each group to assess the resilience for the next process. In this study, we limited the study area to four case study villages ${ }^{(2)}$ in four communes ${ }^{(3)}$ designated as group I to group IV: these were the villages of Tuy Loan Dong 2 (Hoa Phong - a hilly and mountainous commune), Cam $\mathrm{Ne}$ (Hoa Tien - a flatland commune), Hoi Phuoc (Hoa Phu - a mountainous commune), and Tay An (Hoa Chau - a flatland commune), respectively. The village in group V (Loc My) was not selected because evaluation of the field survey showed that the flood pillar was far from the residential areas and the value of highest historical flood depth was lower $(1.8 \mathrm{~m}$ flood depth value from the bottom of flood pillar) than those measured in the other villages (average flood depth value from 2.65-3.64 m).

\section{Community Resilience Measurement}

(a) Overall sample

Applying a 5\% error margin, household questionnaires were administered to 92, 130, 44, and 34 households of Tuy Loan Dong

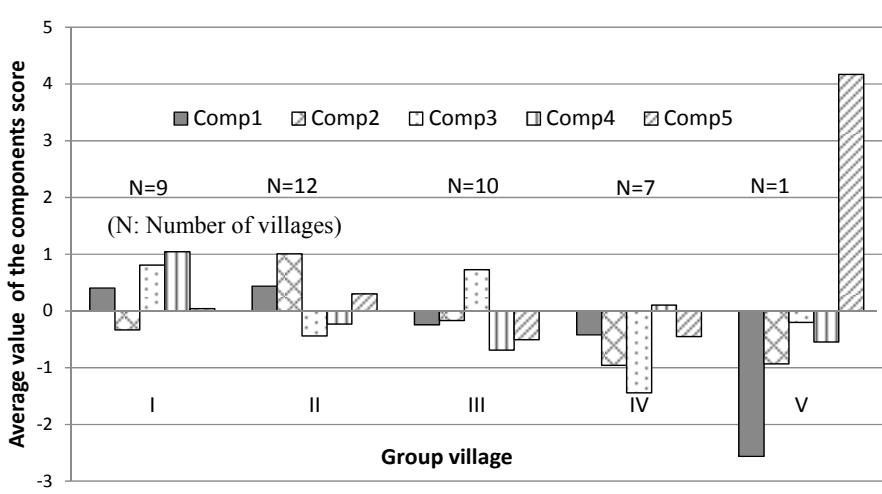
2, Cam Ne, Hoi Phuoc, and Tay An villages, respectively (representing $27 \%$ of those villages' respective households), for a total of 300 households. Results from the overall sample of the household survey indicated that the sample is not particularly unequal in terms of gender, comprising $42 \%$ female and $58 \%$ male respondents. On average, $43 \%$ of the sample respondents had a secondary level of education, varying from $36 \%$ in Hoi Phuoc village to $50 \%$ in Tay An village. The majority of the sample (67\%) was aged between 25 and 65 years old, while those under 25 and above 65 years old accounted for $5 \%$ and $28 \%$, respectively. In terms of experience of a flood disaster, more than $96 \%$ of all respondents in

Fig. 4 Groups of potential vulnerability villages

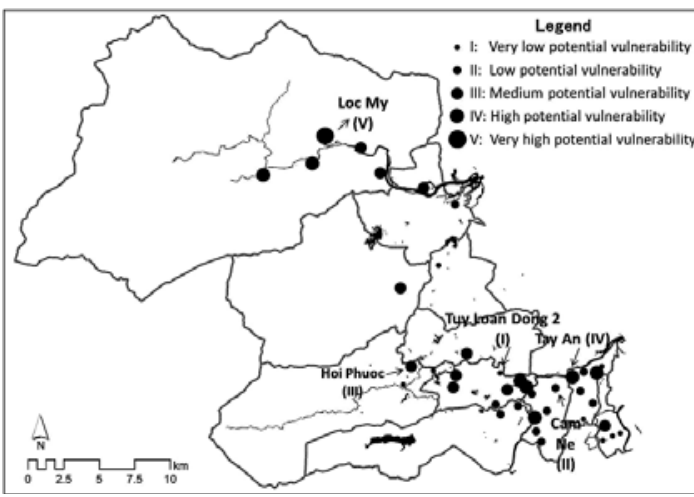

Fig. 5 Map of potential vulnerability group typology

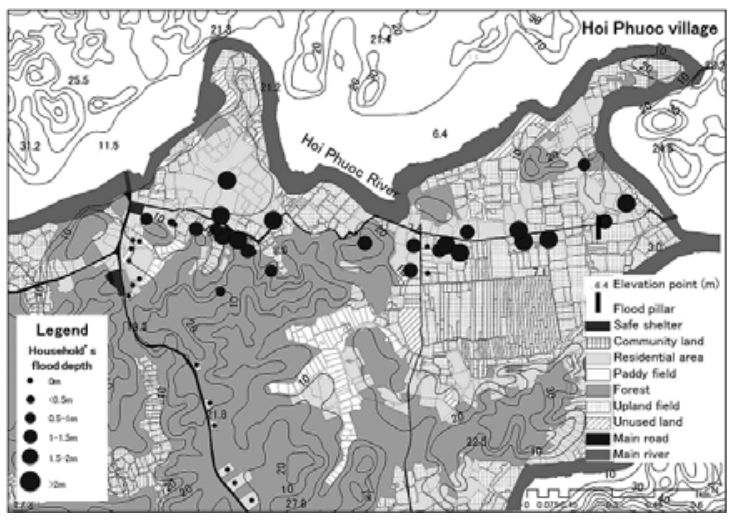

(c)

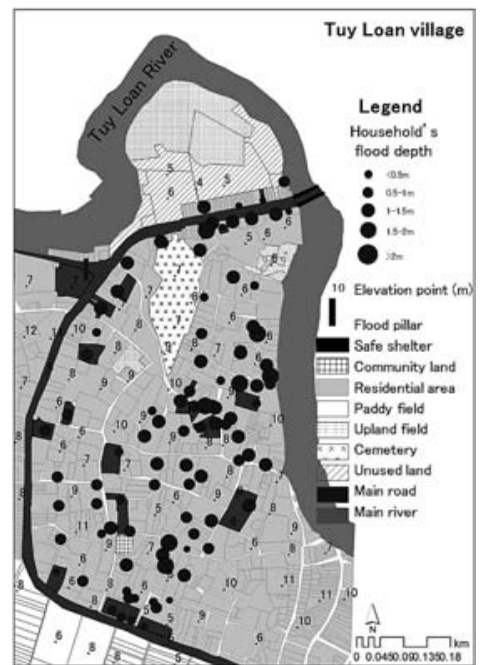

(a)

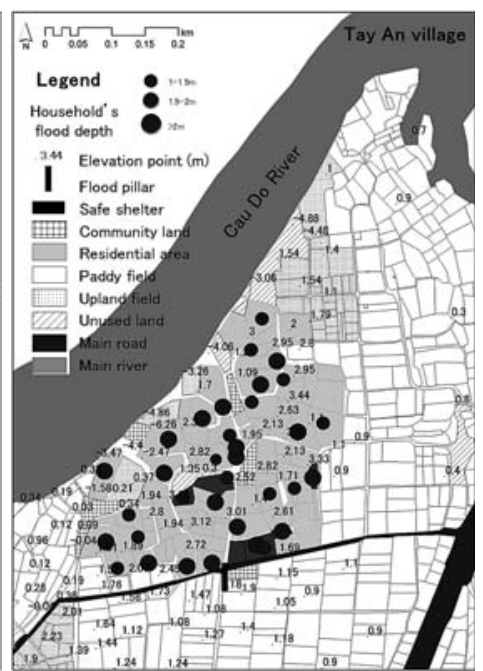

(b)

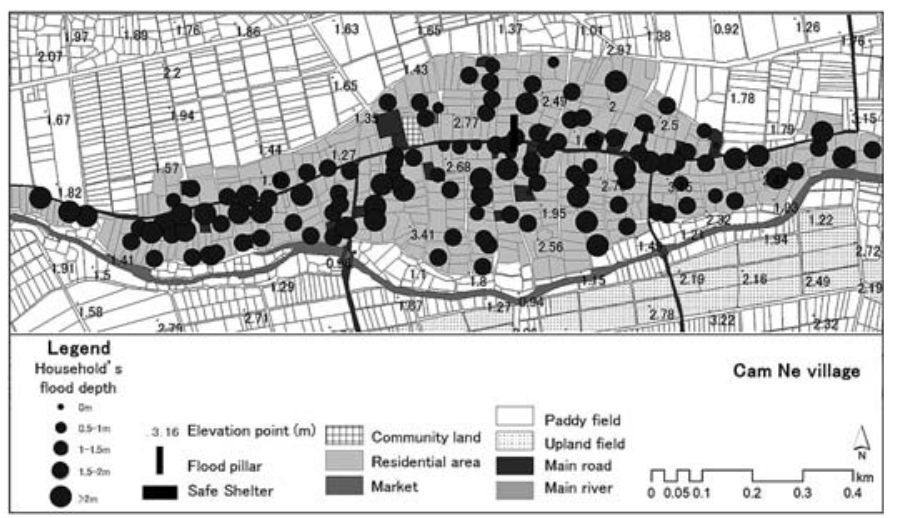

(d)

Fig. 6 Spatial distribution and flood disaster experience of household survey in targeted villages (a) Tuy Loan village (b) Tay An Village (c) Cam Ne Village (d) Hoi Phuoc village 
Tay An, Tuy Loan Dong 2, and Cam Ne were affected households, ranging from $96.9 \%$ in Cam Ne to $100 \%$ in Tay An. These villages are located in a low altitude area, near the vicinity of water bodies, and are considered to be more susceptible to flooding than the whole villages (chronic flooding areas). However, in Hoi Phuoc village, only $59 \%$ of respondents claimed to have experienced a flood disaster. The reason for this is two-fold: on one hand, they live in a mountainous area with high elevation; on the other hand, this area experienced a serious flash flood in 1999, which affected only a portion of the residents in this village. The results also point out that the highest flood depth experience was in the range of $1.5-2 \mathrm{~m}$, comprising $57.7 \%, 41.2 \%, 37.0 \%$, and $18.2 \%$ in Cam Ne, Tay An, Tuy Loan Dong 2, and Hoi Phuoc villages, respectively (Figure 6). This sample size is large enough and reasonably represented the flood disaster experience of the residents to analyze the resilience of rural people to flood disasters

(b) Analysis of community resilience

The overall community resilience was mapped by calculating each capital (economic, social, and environmental) for the four target villages. A detailed radar diagram of each capital dimension of community resilience and overall community resilience is presented in Figure 7.

The economic capital points out the considerable difference in the range of scores between the variables. For instance, accessibility variables appeared to differ among the villages, where Hoi Phuoc had the highest score, followed by Tuy Loan Dong 2 and Cam Ne, whereas the savings variable seemed to have a relatively low and equivalent level for most of them. Almost all of the respondents stated that they have to earn and save money for their daily lives and it was not necessary to save money for coping with disaster. Variables of house conditions and income seemed to decline the economic capital of resilience. This is likely due to the limited capacity of rural residents to generate income (dependent on agricultural activities, low opportunities for employment), which leads to low level of housing conditions. However, only Tuy Loan Dong 2 showed the highest capital in the income per capital variable because it is located near the administrative center of Hoa Vang district and has a high number of households that work in the non-agriculture section. In brief, households in Hoi Phuoc are more resilient to flood disasters in terms of economic capital when compared to the other villages.

The social capital of the villages, as indicated by the household survey results, had more variables that appeared to show a relatively auspicious level. Community cohesiveness variables showed a relatively high score (average of 2.6) but a difference was still apparent among the four villages. Tay An residents formed a less cohesive community, especially in terms of attendance at community activities as well as joint discussions to solve community issues. The variables of community cohesiveness indicated that all villages have made an effort to take action to prevent and mitigate natural disasters and that the villages have a high belief in having a prosperous community in the future. Likewise, looking at institutional aspects shows a large variation between Hoi Phuoc and the other villages, ranging from 2.9 (in Hoi Phuoc) to 1.9 (in Tay An) on average. This strength in Hoi Phuoc village may be due to its experiences learned from the serious damage due to the flash flood in 1999 and good community collaboration as well as residents' awareness followed by well-functioning institutional activity in forming a development plan that addresses natural disaster issues. Aspects of education, satisfying life, community preparation, and community participation in disaster-related activities were not significantly different among the villages and had low scores, contributing to a decline in the social capital of resilience. Community participation in particular seemed to be fragile in most of the villages. However, in general, the form of the radar diagram for social capital was homologous in most villages and revealed the highest score when compared with the other capitals.

The environmental capital showed a significant variation in each variable between the villages. Tay An village highlighted a low score in most of variables of environmental capital, especially in drainage system, water quality, and sanitation conditions. Conversely, Hoi Phuoc showed an advanced score in those variables of environmental quality, with an average of 2.9. The shape of the radar diagram clearly shows that the level of flood depth does not closely relate to the flood damage degree in most of the villages. The reason for this could that the damage to residents by flood hazards was not only due to the flood depth but also to other factors such as the living conditions as well as the level of preparation to cope with flood hazards. The proximity variables reveal differences between the villages due to their dissimilar spatial distribution. Overall, community resilience shows higher values for social capital, followed by environmental capital. This reflects the characteristics of rural residents, who still maintain their social networks and community cohesiveness, as well as a willingness to provide support to other people during disaster events. The results indicated the highest score of community resilience to flood disaster in Hoi Phuoc, followed by Cam Ne and Tuy Loan Dong 2.

\section{Community Resilience Assessment}

Investigating the typology based on the socio-economic and topographic characteristics of the flood affected villages allowed extraction of the potential vulnerability of villages and was used for analyzing the community resilience. Examining the relationship between potential vulnerability typology and community resilience with respect to the actual condition of flood disaster related issues in the four villages yielded the assessment of community resilience shown in table 4.

In terms of potential vulnerability, Tay An village was classified into group IV (High potential vulnerability), characterized by a negative value in most components such as "Level of living conditions", "Scale of population", "Level of labor force", and "Housing conditions" (Figure. 4 and Table 3). The questionnaire survey showed that Tay An formation could be classified as showing medium community resilience but with a lower score than Tuy Loan Dong 2 and Cam Ne. Geographically, Tay An is located in the most low-lying region of the Hoa Vang district, and it suffers high flood

Table 4 Community Resilience Assessment in 4 villages

\begin{tabular}{lllll}
\hline No & \multicolumn{1}{c}{ Village } & $\begin{array}{c}\text { Potential } \\
\text { Vulnerabi } \\
\text { lity }\end{array}$ & $\begin{array}{l}\text { Community } \\
\text { Resilience }\end{array}$ & $\begin{array}{l}\text { Problems relate } \\
\text { to flood disaster }\end{array}$ \\
\hline 1 & Tay An & High & Medium & Much trouble \\
2 & Tuy Loan Dong 2 & Very low & Medium & Less trouble \\
3 & Cam Ne & Low & Medium & Less trouble \\
4 & Hoi Phuoc & Medium & High & No trouble \\
\hline
\end{tabular}


damage to livelihood and life, as well as infrastructure. About 20 riverine households are exposed to a high frequency of river landslides and are always must prepare to relocate when floods occur. In addition, the progression of urbanization has enabled the formation of new urban areas as well as widening highways surrounding Tay An village but these are at different elevations. This had led to Tay An becoming an island separated from the surrounding areas time of heavy flooding. The assessment results as well as the actual situation show that Tay An will have significant trouble in its response and recovery when faced with a flood disaster. Therefore, the local government as well as residents urgently needs to develop solutions to reduce social vulnerability and simultaneously enhance the resilience of community to a higher level to meet the requirements of a new rural development program.

Tuy Loan Dong 2 and Cam Ne show

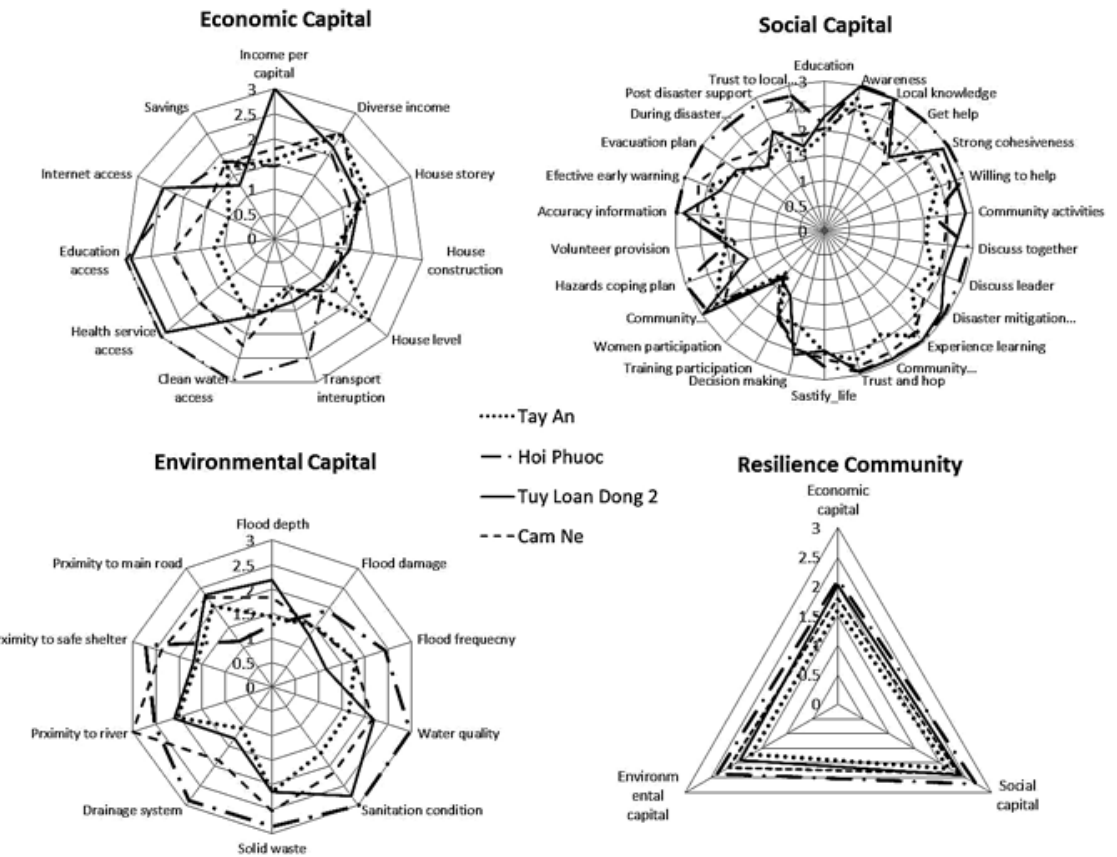

Fig. 7 Resilience Community for 4 villages in Hoa Vang Rural district

relatively equivalent results in assessment of community resilience. Although Cam Ne and Tuy Loan Dong 2 village are evaluated with respectively low and very low potential vulnerability in social aspects, both had a medium score among the four villages when evaluated as resilient communities. This result infers that these villages will have less trouble in response and recovery when faced with a flood disaster. However, with the relatively low topographic features, combined with frequent flood hazards, Tuy Loan Dong 2 and $\mathrm{Cam} \mathrm{Ne}$ need to further enhance their community resilience.

Hoi Phuoc is considered to have a relatively high capacity for resisting flood disasters, with a high level of community resilience potential and a medium level of potential vulnerability. This may be due to its high level of environmental capital - which is defined as the crucial component for a strongly resilient community that is inextricably linked to the condition of the environment and natural disaster, combined with the positive aspect of socio and economic capital that increases the level of resilience of the community to a natural disaster. In addition, this village has not been exposed to high flood hazards in recent years. From these results, Hoi Phuoc was assessed as being in "no trouble" in its response and recovery when faced with a flood disaster. However, its complex topography, being located in the lower section of upstream (Lo Dong and An Loi River), Hoi Phuoc shows a high potential for flash floods. Therefore, the local government needs to pay attention to maintain the high degree of resilience to flood disasters.

\section{Conclusion}

The findings in this study show that examining community resilience in relation to vulnerability is essential in order to understand how communities respond and adapt to natural disasters. Quantitative and qualitative analysis of community resilience via a capitalbased approach can facilitate comparisons between different villages as well as determine how strengths and weakness of the each capital contributes to ensure community resilience.

The use of typology in zoning rural flood affected villages as a background for community resilience assessment is an effective and novel approach to flood disaster related research in rural Vietnam. Based on the case study results, this approach can provide fundamental science for authorities to base their policy decisions for building reasonable policies and solutions for prevention, response, and mitigation of natural disasters in specific regions. Specifically for the implementation period of the New Rural Development in Hoa Vang district, identifying these issues will support the decision to have the correct orientation in new rural planning integrated with mitigation and adaptation to climate change. The outcomes of this assessment reveal the current capacities of communities to initiate contextualized community - led planning and implementation of household responses in form of actions to enhance the community resilience to flood disaster. In this study, a number of solutions for improving rural community resilience for each village were identified, as follows:

* Tay An village:

- In terms of minimizing potential vulnerability, some policies should focus on enhancing housing conditions and livelihood quality, as well as diversifying the income of the local residents.

- In terms of enhance the community resilience: First, the village needs to provide investment support to improve the structural risk reduction measures for riverine embankments and evacuation routes, as well as enhance environmental quality. As a long term strategy, the local government should increase awareness and participation of the local residents and establish detailed natural disaster prevention plans for households in the village. 
* Tuy Loan Dong 2 and Cam Ne villages: In implementing the new rural planning, disaster risk management should be integrated into the community's socio-economic development plans, such as by improving the quality of the rural environment and enhancing household preparedness strategies to ensure the village's sustainable development.

* Hoi Phuoc village: Strengthening the watershed forest growth and protection to improve water control when floods occur will help to prevent and limit flash floods in the upstream regions.

The results will serve as a good reference for policy decision-makers as well as local authorities in order to carry out solutions and policies that can enhance the resilience of rural community in specific regions and meet the objectives of the new rural development program to withstand the effects of climate change and unpredictable natural hazards.

Note

(1) Water warning level is isued by Vietnam state agency. It is used to alert when river water levels appear to exceed those warning level. According to the Decision No 632/QD-TTG of Prime Minister, River water warning level is divided into 3 main levels as level I, II, III correspond to possible flood condition, Dangerous flood condition, and Very dangerous flood condition, respectively.

(2) The village is an important form of society in rural Vietnam. A commune is a gathering of some villages. A village is not considered an administrative level in the administrative system of Vietnam. It is an autonomic/self-governing organization of a certain community in the common local residents. The government operation of a village is managed directly at the commune level. Villages in the plain areas have population sizes of over 200 households, villages in mountainous, frontier, and island areas have population sizes of over 100 households.

(3) The administrative classification system of Vietnam includes three levels: provincial, district, and communal/ward levels (the commune is the lowest basic administrative level). Mountainous communes are characterized by populations from 1,000-14,000 people with an area in range of 1,000-8,000 hectares. Plain communes are characterized by populations from 2,000-16,000 people with an area of 500-6,500 hectares (Vietnam Government Decree No.159/2005/NĐ-CP Classification administrative unit of Commune, Ward and Township).

\section{Acknowledgment}

The authors would like to thank Mr. Tran Triet Tam, Head of Demographic - Social - Economic Division, Da Nang Statistical Office for his kind support in providing invaluable census data and advising in very constructive comments on Household Questionnaire Survey for this paper. The authors also acknowledge with gratitude the young staffs of Hoa Vang Statistical Office for their assistance during the questionnaire survey execution in June and July, 2013.

\section{References}

1) ACCCRN, 2009, Asian Cities climate change resilience network (ACCCRN): Responding to urban climate challenge, ISET, Boulder, CO, 60pp.

2) Adger, W.N., 2000, Social and ecological resilience: are they related? Progress in Human Geography, Vol.24, No.3, pp. 347-364.

3) Adger, W.N, 2006, Vulnerability, Global Environmental Change. ELSEVIER. Vol.16, pp. 268-281.

4) Ainuddin S., 2012, Community resilience framework for an earthquake prone area in Baluchistan. International Journal of Disaster Risk Reduction, Vol.2, pp. 25-36.

5) Centre for International Studies and Cooperation (CECI), 2008, Program for Hydro-Meteorological Disaster Mitigation in Secondary Cities in Asia - Vietnam - Final Report, Asian Disaster Preparedness Center.

6) Challenge to challenge and Hue University (2009), Hazard Capacity and Vulnerability Assessment in Da Nang Report, Asian Cities Climate Change Resilience Network.

7) Cutter, S.L., Barnes, L., Berry, M., Burton, C., Evans, E., Tate, E., Webb, J., 2008, A place-based model for understanding community resilience to natural disaster, Global Environmental Change, Vol.18, pp. 598-606.

8) Da Nang's Committee for Flood and Storm Control (2008), Natural disaster report of Da Nang, Da Nang (In Vietnamese)

9) Da Nang Statistical Office (2010), The 2009 Da Nang city population and housing census: Completed results, Statistical Publishing House, Vietnam (In Vietnamese).

10) Fekete, A., 2009, Validation of a social vulnerability index in context to river-floods in Germany, Natural Hazards and Earth System Sciences, Vol.9, pp. 393-403.

11) Folke, C., 2006, Resilience: The emergence of a perspective for social-ecological systems analyses, Global Environmental Change, Vol.16, pp. 253-267.

12) Hoa Vang Statistical Office, 2011, The 2011 Census Data on Rural Agriculture - Aquaculture, Hoa Vang district, Da Nang city, Vietnam (In Vietnamese).

13) Holling, C.S., 1973, Resilience and Stability of Ecological Systems, Annual Review of Ecology and Systematics, Vol.4, pp. 1-23.

14) Huong, D.T.V., Nagasawa, R., Tsutsui, K., 2013, Analysis of urban expansion and flood risk change in Da Nang city in Central Vietnam, Journal of the Japanese Agricultural systems society, Vol. 29, No.3, 123-134.

15) Inotaga K., 2012, Resilience of Rural Community through Emigration and Return, Journal of Rural Planning Association, Vol.30, No.4, pp. 536566 (In Japaneses).

16) International Strategy for Disaster Reduction (ISDR), 2004, Living with Risk-A global review of disaster reduction initiatives, Vol.1, United Nations, New York and Geneva, 457 pp.

17) International Strategy for Disaster Reduction (ISDR), 2005, Hyogo Framework for Action 2005-2015: Building the Resilience of Nations and Communities to Disasters, World Conference on Disaster Reduction, Kobe, Hyogo, Japan, 22 pp.

18) Japan ICOMOS National Committee, 2011, The Great East Japan Earthquake - Report on the Damage to the Cultural Heritage, 32pp. In http:// www.icomos.org/publications/ICOMOS\%20Japan-earthquake_report_20111120.pdf, Accessed on January 23rd 2014.

19) Joerin, J., and Shaw, R., 2011, Mapping Climate and disaster resilience in cities, Community, Environment and Disaster Risk Management, Vol.6, pp. 47-61.

20) Kienberger, S., Johnson, F.A., Zeil, P., Hutton, C., Lang, S., Clark, M., Modelling socio-economic vulnerability to floods: Comparison of methods developed for European and Asian case studies Research and Innovation. In http://ec.europa.eu/research/sd/conference/2009/papers/4/Stefan kienberger_-_socio-economic_vulnerability.pdf, Access on May 6th 2012. 
21) Klein, R.J.T., Nicholls, R.J., Thomalla, F., 2003, Resilience to natural hazards: How useful is this concept? Environmental Hazards, Vol.5, pp. 3545.

22) Kumar, C., 2005, Revisiting 'community' in community-based natural resources management, Community Development Journal, Vol. 40, pp. 16-20.

23) Manyena, S.B., 2006, The concept of resilience revisited, Disaster, Vol.30, No.4, pp. 433-450.

24) Mayunga, J. S., 2007, Understanding and Applying the Concept of Community Disaster Resilience: A Capital-based approach, In http://www.ehs. unu.edu/file/get/3761, Access on April, 28th, 2013.

25) Norris, F.H., Stevens, S.P., Pfefferbaum, B., Wyche, K.F., Pfefferbaum, R.L., 2008, Community resilience as a metaphor, theory, set of capacities, and strategy for disaster readiness, American Journal of Community Psychology, Vol.41, pp. 127-150.

26) Paton, D., Smith, L., and Violanti, J., 2000, Disaster response: risk, vulnerability and resilience, Disaster Prevention and Management, Vol.9, No.3, pp. 173-179.

27) People's Committee Da Nang, 2009, Report on State of Coping with Natural Disaster for last 10 years in Da Nang city, People Committee Da Nang, Da Nang, pp. 10 (In Vietnamese).

28) People's Committee Da Nang, 2012, Action Plan of Responding to Climate change and Sea Level Rise to 2020, Da Nang, pp. 51 (In Vietnamese).

29) Pfefferbaum, R.L., Pfefferbaum, B., and Horn, V.R.L., 2011, Communities Advancing Resilience Toolkit (CART): The CART Integrated System. Oklahoma City, OK: Terrorism and Disaster Center at the University of Oklahoma Health Science Center, pp. 87.

30) Razafindrabe, B. H., Shaw, R., Arima, M., 2009, Resilience of Urban Communities in a Changing Climate and Environment - Focus on water related Issues in Central Vietnam

31) Shaw, R. and Sharma, A., 2011, Climate and disaster resilience in cities, Community, Environment and disaster risk management, Vol.6, Emerald Group Publishing Limited.

32) Sherrieb, K., Louis C.A., Pfefferbaum R.L., Pfefferbaum B.J.D., Diab E., Norris F.H., 2012, Assessing community resilience on the US coast using school principals as key informants, International Journal of Disaster Risk Reduction, Vol. 2, pp. 6-15.

33) Son, M.T., Phung, L.D., Thinh, L.D., 2011, Climate change: Impact, response capacity and policy issues (Case study of ethnic minority un Northern Mountains) (In Vietnamese), In http://www.ngocentre.org.vn/webfm_send/2954, Access on September 6th 2012

34) Thinh, N.V., Duc D.T.M, 2001, Textbook on Socio-economic Geography of Vietnam, Education Publisher, Ha Noi, Vietnam (In Vietnamese).

35) Turner, B.L., Kasperson, R. E, Matson, P.A., McCarthy, J.J., Corell, R.W., Christensen, L., Eckley, N., Kasperson, J.X., Luers, M., Martello, M.L., Polsky, C., Pulsipher, A., and Schiller, A., 2003, A framework for vulnerability analysis in sustainability science, National Academy of Sciences of the United States of America, Vol.100, No. 14, pp. 8074-8079.

36) Tsutsui, K., 2005, The Geography Character of Local Public Investment in Vietnamese Rural Area in the 1990s, Annuals of the Association of Economic Geographers, Vol. 51, No.3, pp. 242-260 (In Japanese).

37) U.S. Indian Ocean Tsunami Warning System Program, 2007. How resilience is Your Coastal Community? A guide for Evaluating Coastal Community Resilience to Tsunami and Other Coastal Hazards. Indian Ocean Tsunami Warning System Program supported by the United Stated Agency for International Development and partners, Bangkok, Thailand. 144p.

38) Vietnam Ministry of Natural Resources and Environment, 2008, National Target Program on Response to Climate change, Ha Noi, Vietnam, pp.71 (In English).

39) Wisner, B., Blaikie, P., Cannon, T., and Davis, I., 2003, At Risk: Natural hazards, people's vulnerability and disasters, Routledge, New York, 134 pp.

40) Western, J., Stimson, R., Baum, S., and Gellecum, Y.V., 2005, Measuring community strength and social capital, Regional Studies, Vol. 39, No.8, pp. 1059-1109.

41) Wickes, R., Zahnow, R., Mazerolle, L., 2010, Community Resilience Research: Current Approaches, Challenges and Opportunities, Institute for Social Science Research, The University of Queensland, $29 \mathrm{pp}$.

42) Wilson, G.A., 2012, Community resilience, globalization, and transitional pathways of decision-making, Geoforum, Vol 43, pp. $1218-1231$.

43) Wilson, G. A., 2012, Community Resilience and Environmental Transition, Routledge, London and New York. 251 pp.

44) World Bank, 2013, Vietnam: Disaster Risk Management Project, In: http://www.worldbank.org/en/results/2013/04/09/vietnam- -disaster-riskmanagement-project. Accessed on September, 16th 2013.

45) Yamane, T., 1967, Elementary sampling theory, Prentice-Hall, Inc., Englewood Cliffs, N.J.: Prentice-Hall.

\section{《日本語要約》}

レジリエンスとは回復力や弾性力と解され，災害などで打撃を受けたコミュニティを維持，再生していくためにコミ ユニティレジリエンスが必要とされる。本研究では, ベトナム中部に位置するダナン市の農村地域における洪水梁害に 対するコミュニティレジリエンスを, Wilson, G. A（2012）の概念枠組みを修正して導入し，実証的に評価した。まず 社会経済状沉から潜在的な脆弱性を把握するため, 洪水被害を受けた村（集落に相当）の地域類型化を行い, それぞれ の類型から合計 4 つの対象地域を抽出した。そして世帯アンケートを通じて経済資本, 社会資本, 環境資本の側面から コミュニティレジリエンスの状況を把握し, 先に明らかにした地域類型の特徵と, 洪水被害の実態, さらに土地条件を 勘案した評価を行った。この手法を用いることで, 農村地域の潜在的な脆弱性とコミュニティレジリエンスの双方を勘 案した洪水災害への強さ／弱さを明確に捉えることが可能となった。

Key words: Community Resilience, Vulnerability, Regional Typology, Da Nang City, Vietnam キーワード：コミュニティレジリエンス, 脆弱性, 地域類型化, ダナン市, ベトナム 